\title{
Selling the PSS in a School of Business:
}

\section{Relationship Selling In Practice}

\author{
David Titus ${ }^{1}$, Garth Harris ${ }^{1}$, Rajesh Gulati ${ }^{1} \&$ Dennis Bristow ${ }^{1}$ \\ ${ }^{1}$ Herberger Business School, St. Cloud State University, St. Cloud, MN, USA \\ Correspondence: Dennis Bristow, Herberger Business School, St. Cloud State University, St. Cloud, MN USA. Tel: \\ 1-320-308-5125.
}

Received: January 19, 2017

Accepted: March 2, 2017

Online Published: April 7, 2017

doi:10.5430/ijhe.v6n2p182

URL: https://doi.org/10.5430/ijhe.v6n2p182

\begin{abstract}
This paper presents a step-by-step process for the development and implementation of a professional selling specialization program in the marketing curriculum of a school of business at an AACSB accredited state university. The program is presented in detail along with the process followed in order to develop support for the program with three primary stakeholders: faculty, administrators, and regional and national employers. Ongoing program challenges, successes, and growth opportunities are discussed. Program outcomes and stakeholder perceptions are included.
\end{abstract}

Keywords: Marketing, Professional selling, Sales program

\section{Introduction}

Demand for well-trained, college educated sales professionals remains strong and is predicted to grow through 2024 (Occupational Outlook Handbook 2017). Research shows that between $70 \%$ and $80 \%$ of marketing major graduates, and between $60 \%$ and $70 \%$ of all business graduates, will spend at least part of their careers in professional selling (Stevens \& Kinni, 2007). And, as reported in their 2014 Journal of Marketing Education article, Bolander, Bonney and Satornino note that more and more schools of business, and marketing departments within those schools, are including professional selling as an educational focal point in their curricula. This paper outlines the challenging (and rewarding) road one academic unit in a state university traveled in order to add a professional selling specialization program to the marketing curriculum.

\section{Background}

The work presented here was conducted in the Herberger Business School (HBS) at St. Cloud State University (SCSU), a unionized institution located in Minnesota, USA. The university has been AACSB accredited for nearly 40 years and the HBS features 5 major units - Accounting, Finance/Insurance/Real Estate, Information Systems, Management, and Marketing - and offers 8 different majors as well as several specialization areas. The Professional Selling Specialization (PSS) program discussed in this paper is one of those specializations and is housed in the Marketing Department. The program requires students to complete 5 academic courses ( 15 credits total), to complete a sales personality assessment and to participate in at least one professional selling competition in order to earn the Professional Selling Specialization. Those 5 courses are:

- Introduction to Marketing ( 3 academic credits)

- Marketing Communications (3 academic credits)

- Professional Selling (3 academic credits and participation in the Professional Selling Competition)

- Sales Management (3 academic credits; new course added to the curriculum)

- Sales Capstone (3 academic credits and participation in the Professional Selling Competition; new course added to the curriculum)

In September of 2014, the Marketing Department began accepting student applications for admission to the PSS program and the University was recognized by the Sales Education Foundation as a Top Sales University in North America. The application process is online and allows interested students from across the University to log on with their University ID and to provide contact information, GPA, and academic major/minor information. PSS applicants 
must also upload and attach to the application a one page Word document outlining their reasons for pursuing the PSS and how the program fits with their academic and career goals. To be eligible for the program, students must:

* Be admitted to their academic major

* Meet minimum GPA requirements of the Business School or for their academic major program

* Have completed at least 45 credits and achieved upper division program status (this status is required for students to enroll in upper division/senior level courses)

* Achieve a final letter grade of at least a "B" in the Introduction to Marketing course

All applications are reviewed by a 4-member PSS panel of marketing professors and consensus must be reached before an applicant is admitted to the program. The review focuses on the admission requirements outlined above and the applicant's ability to convey, via their application essay, a clear and logical discussion of the fit between their academic and career goals and the PSS program. Upon admission to the PSS, each student is assigned a PSS academic advisor who, in cooperation with the applicant, develops a program plan (course schedule) for completion of the PSS. Upon completion of the program, each student receives an official University Professional Selling Specialization Certificate of Award and the specialization is recorded on the student's official University transcript.

The remainder of this paper provides an overview of the how the PSS was developed and successfully added to the marketing curriculum in the Herberger Business School. The goal of this work is to present a step-by-step process which educators can follow in order to add such a program to their curriculum.

\section{Step 1. Do Your Research -- Customers, Competition, Companies, and Colleagues}

In 2008, the HBS engaged in a comprehensive strategic planning process which included in-depth conversations with and participation by faculty, administrators, and area and regional business leaders. A recurring theme to emerge from this work was the need for the school's marketing department to develop and add a professional selling program to the existing marketing curriculum. [At the time of the strategic plan, that curriculum included only one professional selling course]. In depth analysis of the strategic plan data indicated that the sales program would best serve student needs and would provide them with comparative advantage when seeking sales related internships and when entering the marketplace by providing additional selling courses and emphasizing experiential learning opportunities in business-to-business selling. The strategic plan also revealed that such a program would enable the marketing department to better meet the sales hiring needs of area, regional, and national firms. In addition, the program would provide the University with a point of differentiation in a competitive educational marketplace and would serve as an effective student recruitment and retention tool.

Also included in this first step in the development of the PSS was the collection of extensive documentation of the growing need/demand for university trained salespeople, to gather related statistics provided by the U.S. Bureau of Labor Statistics, to garner information from the professional selling literature and related academic and professional conferences, and to consolidate this information with related findings from the school's 2008 strategic plan. With this information, program proponents created a PSS information packet which included a proposed PSS curriculum.

\section{Step 2. Selling the Sales Program to the Dean and to Marketing Faculty - Get Stakeholders Involved}

In the very earliest stages of the development of the PSS, faculty proponents of the program recognized that universal marketing department faculty support of the program was unlikely. Informal discussions with faculty members revealed that a minority of faculty held strong convictions that professional selling had little or no place in a business school curriculum and that there would be very limited demand for the program. In addition, some faculty expressed their concerns that the program would require additional human, technological, and financial resources. Not surprisingly, the same faculty conveyed their concerns that the program would change the marketing major into a sales major. Relevant statistics from the Bureau of Labor Statistics, the school's strategic plan, testimonials from and presentations by area sales professionals, recruiters, and members of the advisory board were used to address these concerns. Further discussions with these faculty members addressed the concern that the marketing major would become a sales major. It was emphasized that the PSS would not be required of all marketing majors and that the marketing major would continue to offer students opportunities to tailor the major, via other marketing elective courses including global marketing, services marketing, electronic marketing, business consulting, internship/field experience and others, to fit their career goals and plans. It was also emphasized that students pursuing the PSS would still be required to complete the required marketing major courses: New Product Development, Logistics, Integrated Marketing Communication, Marketing Research, Consumer Behavior, and Business Law. It is worth 
noting that, despite these efforts, a small minority of faculty continued to express their concerns with the proposed PSS program.

With these revelations in mind, the sales program proponents realized that initial administrative support/backing of the program would be a valuable tool in terms of selling the program to the marketing faculty. Specifically, it was imperative to obtain commitment from the administrators that if, due to program growth, additional resources were required those resources would be made available. To gain that administrative support, the materials in the PSS information packet were presented to and discussed with the Dean of the HBS. The Dean's initial response to the proposal was positive and she supported further development and refinement of the program and agreed to commit additional growth related program resources as needed.

The PSS information packet and the proposed PSS curriculum were then shared, via multiple presentations and discussion sessions, with marketing department faculty. Faculty were encouraged to share their thoughts, ideas, concerns, suggestions and recommendations for the PSS in general and for the proposed PSS curriculum. A point of emphasis in the earliest discussions of the program with the faculty was the fact that marketing majors could complete the PSS without adding any additional courses or academic credits to their major coursework. At the time of those departmental discussions, the marketing major consisted of and continues to consist of 27 credits plus the Introduction to Marketing course (required of all business majors). These early discussions made clear that 3 of the PSS courses (Introduction to Marketing, Marketing Communications, and Professional Selling) were required of all marketing majors and that the remaining 2 courses in the program (Sales Management and the Sales Capstone course) satisfied the two elective courses necessary to complete the marketing major. Further, these discussions featured the administration's commitment to the program in terms of future additional resource needs. While the majority of the departmental faculty supported the sales program, as expected there was some pushback from a few faculty members who expressed strong skepticism regarding the need for college educated salespeople and, more broadly, the need for a sales program at all in a school of business. (A conversation in January of 2017 with a retired sales trainer from Wells Fargo revealed his frustration with the fact that this perspective is still prevalent on many college and university campuses).

In order to address these concerns, the proponents of the sales program presented detailed statistical reports from the U.S. Bureau of Labor, details from the school's strategic plan, testimonials and input from sales professionals across the region, advisory board members and sales faculty at other universities to the marketing faculty. Not unexpectedly, the input from regional sales experts representing a variety of firms ranging from small, local operations to international logistics firms and multi-national beverage companies seemed to have significant effect in addressing faculty concerns with the program. However, despite those efforts, some faculty continued in their opposition to the PSS, emphasizing two key points of concern: 1) a perceived lack of student demand for the program and 2) the perception that sales people did not need a college degree to succeed in a sales related career. Proponents of the program provided further evidence of program support, and demand for college graduates with specialized knowledge and skills in the sales discipline, in the form of additional testimonials and program commitments from firms such as Frito Lay, Coca-Cola, Wells Fargo, Northwestern Mutual, Penske, Enterprise Holdings, Microsoft, United Health Partners, Federated Insurance, Aerotek, Captial One, C.H. Robinson, Pepsico, Sherwin Williams, Coyote, and others. Additional statistical documentation indicating, for example, that by the close of 2016 some sales firms would lose over $40 \%$ of their sales forces and that by 2020 there will be demand for some 2 million new sales people (Pink 2012) and that professional selling was listed by Buhl (2013) as one of 8 high demand professional certifications was shared with the faculty. Over a period of several months and several presentations/discussion sessions including faculty, administrators and sales professionals the few opposing faculty gradually agreed to support the PSS.

\section{Step 3. Selling the Sales Program to the University Administration - Let the Facts Speak}

Once department support of the PSS was achieved, the next step was to sell the program, in detail, to business school and university administrators. The sales strategy in this phase of the program included sharing the documentation and statistics noted above (in Step 1), along with the fitment of the PSS curriculum with the existing marketing major curriculum as well as the availability of the program to all majors across the University, with those administrators. Informational meetings and discussion sessions were held with business/sales leaders, the business school Dean, the University President and Provost and the sales program champions from the marketing department. This step in the sales process featured two primary goals:

1. To have school and university administrators embrace the mission of the PSS and to convince them that with the proposed curriculum and an externally funded state-of-the-art sales lab/sales suite the 
marketing department could provide students with comparative advantage in the marketplace;

2. To lay the ground work for strong, vibrant and ongoing relationships with area business and the surrounding community and to gain curricular insight from these sales experts.

These 'town hall' type discussion/presentation sessions with business school and university level administrators and area business leaders led to virtually unanimous support for the program. In these sessions one of the key selling features of the program was the relational, value-added link between the marketing department, the school, the university, and the business community. In point of fact, these relationships served as the foundation upon which the PSS was developed. These highly participative sessions provided a venue for the PSS faculty to share the proposed program curriculum with the sales experts and allowed for early and thorough feedback/insights from those same stakeholders. The sessions also revealed that the PSS presented a win-win-win-win scenario: The University would likely benefit from increased enrollments and improved retention rates, the marketing department would likely realize increased numbers of marketing majors and strong relationships with the business community, students would add professional selling skills to their educational portfolio and ultimately gain comparative advantage in the marketplace, and employers would have access to business students with specialized sales skills. At the same time, school and university administrators experienced first-hand the support and enthusiasm exhibited by the sales experts for the PSS.

\section{Step 4. Selling the Sales Program to the Curriculum Committee(s) - Be Ready with the Details}

The next step in developing the sales program was to finalize the PSS curriculum and to shepherd the multiple forms, documents, and discussions through the curriculum process at the business school and university levels. Working in consultation with area business and sales professionals, faculty members developed a 15 credit, 5 course curriculum for the program: Course 1: Introduction to Marketing (existing course required of all business majors); Course 2: Marketing Communications (existing course required of all business majors); Course 3: Professional Selling (existing course required of all marketing majors); Course 4: Sales Management (newly developed marketing major elective course); and Course 5: the 4 module Sales Capstone (newly developed marketing major elective course). The four modules, which were developed via consultation with sales professionals and discussion with sales faculty at universities offering sales programs, include Social Media and Technology in Sales; Global and Cultural Impact on Sales; Sales Shadowing; Sales Management Shadowing.

This step in the development of the PSS program, while seemingly straightforward, soon revealed twists and turns and changing terrain as, once again, a few departmental faculty members pushed back against the sales program. After many meetings, conferences, and revisits to related documentation and further emphasis of the fitment of the program within the existing marketing curriculum, the sales program curriculum was accepted and approved at both school and university levels of the curriculum process.

\section{Step 5. Selling the Sales Program to the Community and Area Business Professionals - Promote and Collaborate}

At this point, the champions of the program would have liked to take a literal breath, to relax and celebrate having successfully navigated a challenging stretch of the sales program road. However, much of the road to implementing the sales program lay ahead. In essence, the department had a viable sales program - a program that hinged upon the participation of area sales experts. It was now time to officially solidify and quantify the financial and personnel support and participation of area business and sales leaders for and in the program. One of the most important steps on this leg of the journey was to secure the financial support of at least one sales firm for a major sponsorship of the program and the program facilities (namely, a 3-room sales suite: The sales control room, the sales simulation room, and the sales classroom). The technology for the suite included computers, three high-definition digital cameras, projectors, office furnishings, network/Cloud capability and more - at a price tag of some $\$ 60,000$. Conversations were initiated with business leaders who were marketing department alums and/or who had strong ties and records of involvement with the business school. Working with the University's Foundation Office, agreement was reached with a firm for a six-figure financial sponsorship of the sales lab/suite and the sales program in return for naming rights to the facilities. With this key piece of the support puzzle in place, the sales program leaders reached out to a variety of business and sales experts in an attempt to solidify additional 'community partners' for the program. The responses to those attempts and the subsequent support was nearly overwhelming. Firms began contacting PSS leaders asking to participate in the program as guest lecturers, coaches, mentors, competition judges/evaluators and more. From the very start of the PSS, dozens of firms began and continue to actively seek PSS students for sales internships and business-to-business sales positions upon graduation. Many firms are working with program leaders to develop sales scholarships for students enrolled in the program. In order to address a plethora of requests from 
sales professionals to present in our sales classrooms and increase their involvement with our sales students, PSS leaders are currently exploring the development of a Professional Selling Speakers Bureau. Several firms and some University units have asked the department to provide sales training to their current employees.

\section{Step 6. Selling the Sales Program to the Students - Career Opportunities and Rewards}

One of the areas of concern voiced by some marketing faculty was that of student demand - or lack thereof -- for the PSS. Acknowledging that many students initially hold negative perceptions of professional selling as a career, the PSS faculty leaders worked with the business school's Communications Office to develop a promotional campaign targeting students across the University. The campaign included not only the PSS requirements but also featured information related to employer support and demand, the logos of major businesses supporting the program, comparative advantage for the students, sales related internship and career opportunities and more. It is important to note that the sales program is available, via the application process, not only to business majors but also to any university student who has been accepted into their academic major. With this in mind, the promotional campaign was disseminated across the University on social media sites, posters and flyers, table tents and television monitors. In addition, the program was and continues to be touted in the school's academic advising and career placement offices with all business majors, in our classrooms, with student groups, and more. In one of our sales courses, we have implemented a program which requires groups consisting of 3-4 students to make at least 2 'Selling the Sales Program' presentations in classrooms outside of the school of business. In addition, PSS students participate in a telephone recruitment campaign by which they reach out to area high school juniors and seniors to tout the benefits of the sales program.

A key component in the early promotion of the PSS occurred in the Fall semester of 2014. An open-house ribbon cutting ceremony was held to celebrate the opening of the new sales lab/suite and the implementation of the PSS. Students, faculty, administrators (including the University President and Provost), media representatives and area business leaders were invited for tours of the new sales suite, discussion of the program, dinner, and networking. The event, and the sales lab and program, have received (and continue to receive) significant amounts of positive publicity in area media outlets, including a front page lead story in the local newspaper, radio interviews, coverage in the University news book, and more.

The promotion of the sales PSS continues and positive results and growth are occurring in the program. To illustrate that growth consider the following:

1. In the 2016/17 academic year, more than 70 students are enrolled and actively pursuing the Professional Selling Specialization.

2. PSS students have received internship and job offers from firms including but not limited to Microsoft, Northwestern Mutual, Anderson Trucking Services, Penske, Enterprise Holdings, Coyote, Cintas, Target, Coca Cola, Pepsico and more.

3. Each semester, the marketing department hosts a professional selling competition. In the first semester of that competition, 14 students participated; in the Fall 2016 competition, some 70 students participated and in the Spring 17 competition, approximately 100 student competitors are expected.

4. Multiple firms sponsor each sales competition, with sponsorship donations ranging from $\$ 500-\$ 2500$.

5. Some 50 sales professionals representing 25 business firms serve as judges and/or buyers during the sales competitions.

6. More than 20 organizations participate each semester in the Professional Selling Career Fair (held each semester concurrently with the sales competition).

7. The Professional Selling Advisory Board has been created to provide real-world insights to curriculum development and industry trends/needs.

8. The creation of a Professional Selling Speaker's Bureau is under discussion and planning.

9. Students are actively seeking additional information about the sales program from their academic advisors.

10. PSS students are competing successfully at regional, national, and international professional selling competitions.

11. The PSS recently earned the Rookie of the Year and Rising Star awards at the 2016 International Collegiate Sales Competition. 
12. To meet growing student demand for the PSS, a national search is underway for a new probationary Marketing faculty member.

As evidenced by these illustrative testimonials, student and employer perceptions of the PSS and the related selling experiences are quite positive:

When I first started the Sales Program I had a negative idea of sales, and a bad perception of salespeople. I had no idea that my opinion would completely change throughout the program, and that I would gain valuable experience that would benefit me in my future (even if that future did not include sales.) The program has given me a solid skills base to understand how to professionally sell products and services as well as how to sell myself, and my ideas in any situation. The combination of learning in class and getting hands-on experience from the Sales Competition has allowed me to apply the knowledge I've gained in a real-world situation. The Sales Competition has been one of the highlights of my college career by being able to showcase my skills to tons of hiring employers. I have made multiple connections with a variety of employers who have invited me for interviews. No matter if I were a bio-med student or graphic design major, I would recommend this program to any student. The skills you acquire will benefit you in any career! --Jasmine (PSS Student)

"I have been involved in the SCSU Sales Competition for the last 4 semesters. I have enjoyed watching the program grow and improve each year! The Sales Competition has begun to truly mirror real-life sales calls. Anything can happen and this experience allows the students to see just that by determining the best way to react to each situation presented to them by the "buyers". I went to the Herberger Business School for Business Management at SCSU and I would have really benefited from a program like this to help me prepare for my future career in sales and account management." -- Kayla (Industry Professional)

\section{Conclusion}

In selling the PSS we addressed four major stakeholders: 1) university students, 2) local, regional and national businesses, 3) marketing faculty and 4) university administrators. We were successful in selling the PSS by first conducting in-depth research, identifying the needs of each stakeholder group and by then working with those groups to design a professional selling specialization program that provides added value for all groups. The challenges going forward, as we see them, are to continue to grow the sales program in terms of student numbers and business participation and support. As noted earlier, plans are underway to create a Professional Selling Speakers Bureau; a Sales Program Advisory Board has been created and continues to evolve; several PSS Student Scholarships are in place and more are being developed; Sales Competition sponsors are in place and more are being added each semester. PSS leaders are working with the University Foundation office to secure an endowed Professorship of Professional Selling and discussions have been initiated with the Dean of the HBS to create a PSS Program Director. Our perspective is that a successful sales program has been created and has grown into an integral component of the Marketing curriculum...the challenge now is to keep the program going, growing, and evolving in order to provide value to our students, department, college, university, employers and the community.

\section{References}

Bolander, W., Bonney, L, \& Satornino, C. (2014). Sales Education Efficacy: Examining the Relationship Between Sales Education and Sales Success. Journal of Marketing Education, 36(2), 169-181. https://doi.org/10.1177/0273475314536733

Buhl, Larry (2013). 8 Professional Certifications in High Demand. Career Builder, March $5^{\text {th }}$. https://www.aol.com/article/2013/03/05/high-demand-professional-certifications-programs/20441103/

Bureau of Labor Statistics, U.S. Department of Labor, Occupational Outlook Handbook, 2016-17 Edition, on the Internet at https://www.bls.gov/ooh/sales/sales.htm (visited January 19, 2017).

Pink, D. H. (2012). To Sell Is Human: The Surprising Truth About Moving Others. New York, NY: Penguin Books.

Stevens, H. \& Kinni, T. (2007). Achieve sales excellence. Avon, MA: Platinum Press. 